DOI: 10.17707/AgricultForest.65.4.08

\author{
Dalibor DONČIĆ, Vera M. POPOVIĆ* \\ Željko LAKIĆ, Dragana B. POPOVIĆ, Zdravka PETKOVIĆ ${ }^{1}$
}

\title{
ECONOMIC ANALYSIS OF WHEAT PRODUCTION AND APPLIED MARKETING MANAGEMENT
}

\begin{abstract}
SUMMARY
Wheat is, in quantity, the third largest crop produced in the world and therefore contributes greatly to the world economy both globally and in Serbia and Bosnia and Herzegovina - B \& H. With wheat, worldwide it is sowing about 2.20 million ha annually and in Republic of Serbia wheat cultivated in 588.820 ha. The present trial was carried out to study the growth rates of yield, production and market of wheat in B \& H. During the period 2010-2016, wheat was sown of Bosnia and Herzegovina on 63606.30 ha. There is trend in increasing of areas under wheat with a rate of $0.99 \%$ per year and, it varies. Average yield of wheat during the monitored period was $3.58 \mathrm{t} \mathrm{ha}^{-1}$. Average export of wheat in the tested period was $41750 \mathrm{t}$ and had a tendency to increase with a rate of $25.67 \%$ and variation $(\mathrm{CV}=104.41 \%)$ while average import of wheat was $398750 \mathrm{t}$ and had a tendency to increase with a rate of $0.82 \%$ and variation $(\mathrm{CV}=10.37 \%)$. The highest import was achieved in 2016 (398750 t) and the lowest in 2013. External trade of agro-industrial products and trade liberalization implies the necessity of raising the technological level of production, productivity, efficiency and application of marketing management.
\end{abstract}

Keywords: area, yield, production, market, wheat.

\section{INTRODUCTION}

Wheat (Triticum aestivum L.) is the oldest and most widely cultivated species to which the human race is grateful for its development and civilization. Wheat belongs to the order Poales, family Poaceae, genus Triticum. Wheat is an old crop grown more than 10,000 years ago in Iraq, China and Egypt, then about 5,000 years later it began to be grown in the eastern part of Europe. Wheat is part of the staple diet in every country in the world because of its high nutritional value, rich in carbohydrates and proteins, making it an extremely nutritious. Wheat is a food source for over seven billion of people and is a major food item in many countries of the world (Pavićević, 1991; 1992; Popović, 2010).

\footnotetext{
${ }^{1}$ Dalibor Dončić, Independent University of Banja Luka, Faculty of Economy, Banja Luka, Veljka Mlađenovića 12e, BOSNIA \& HERZEGOVINA; Vera M. Popović (corresponding authors: vera.popovic@ifvcns.ns.ac.rs), Institute of Field and Vegetable Crops, Maksima Gorkog 30, Novi Sad, SERBIA; Željko Lakić, University of Banja Luka, Faculty of Agronomy, Banja Luka, BOSNIA \& HERZEGOVINA; Dragana B. Popović, University of Novi Sad, Faculty of Economy, SERBIA; Zdravka Petković, Academy of Business Professional Studies, Belgrade, SERBIA.

Notes: The authors declare that they have no conflicts of interest. Authorship Form signed online.
} 
With the globalization, the agricultural sector is opened up with the new avenues, especially for food grains enterprises. The cereal crops are of vital importance not only in providing nutritional support but also earning additional income. Among the cereal, wheat is considered as "staple food's grain" in the country (Asodiya Pinakin, 2014). It is grown all over the world for its highly nutritious and useful grain, as one of the top three most produced crops, along with maize and rice. It is used in the production of bread, biscuits, feeds, confectionary, etc. Wheat obviously took a very important place in international trade. Today, it is the basic food for over $70 \%$ of the country's population (7.8 billion). Wheat bread with a nutritive, vitamin and energy value of 8,500-9,400 joules is more nutritious than the bread of other types of grain, as it contains 70$78 \%$ of carbohydrates, $12-17 \%$ of total proteins, $1.2-2.5 \%$ of oil, $0.5-2.0 \%$ of mineral salts (most salts of $\mathrm{Ca}, \mathrm{P}, \mathrm{Fe}$ ) is rich in vitamins $\mathrm{B}\left(\mathrm{B}_{1}\right.$-thiamine, $\mathrm{B}_{2^{-}}$ riboflavin and PP (nicotinamide). Besides flour, significant by-products of wheat grains milling are wheat germs rich in easily digestible proteins and high-quality edible oil and are used to prepare baby food and certain treats (Rakaščan et al., 2019). The quality standards are as follows: $13 \%$ moisture, $76 \mathrm{~kg}$ hectolitre mass and $2 \%$ impurity. Wheat is divided into five classes: Premium: $>15 \%$ protein and hectolitre mass $80 \mathrm{kghl}^{-1}$; I. Class: $13.5-14.99 \%$ protein, hectolitre mass 78 $\mathrm{kghl}^{-1}$; II. class: $12-13.49 \%$ protein and hectolitre mass $78 \mathrm{kghl}^{-1}$; Class III: 10.5$11.99 \%$ protein and hectolitre mass $74 \mathrm{~kg} \mathrm{hl}^{-1} ; 80 \mathrm{kghl}^{-1}$ ); Class IV: $<10.49 \%$ protein and hectolitre mass $<74 \mathrm{~kg} \mathrm{hl}^{-1}$ (Popović, 2010).

Worldwide, wheat accounts for about one-third of the sown cereals area, or about 26\%. Wheat adapts well to the climate and soil, and has many spicies and varieties; there are, also, winter and spring wheat, so it is grown almost all over the world and is included in the euro-types. The best conditions for growing winter wheat are between $30^{\circ}$ and $50^{\circ}$ north latitude. Conditions for growing wheat north to $60^{\circ}$ and south to $16^{\circ}$ north latitude are less favorable (Pedrotti, 2003). Spring wheat has much shorter vegetation than winter wheat, and is more resistant to drought and high temperatures, so it is more suitable for growing in the northern parts $\left(45^{\circ}-67^{\circ}\right.$ north latitude), where such conditions prevail. The richest countries are the largest exporters of wheat, and it is very important for the economy. Due to the large income that is generated from wheat, many countries try to produce their own wheat so that they do not have to import it (Popović, 2010). Climate, soil and yield are inextricably intertwined in natural environments and should therefore be adjusted in order to produce profitable, high-quality food (Maksimović et al., 2018). The success of production depends on genotype, climatic factors, soil and cultivation technology. For successful production, it is necessary to select high-yielding stable genotypes, adequate locality and to apply the correct cultivation technology. The most important climatic conditions are heat, light and water. Before the start of production, an analysis of the soil quality must be done. If the soil is poor with nutrients, extra nutrition of cultivated crops is in need. To take advantage of the high production potential of modern varieties, we must provide them with $150 \mathrm{~kg}$ of nitrogen and 
$100-120 \mathrm{~kg}$ of phosphorus and potassium per hectare. Wheat uses microelements and macroelements for its growth and development. Macro-elements are nitrogen $(\mathrm{N})$, phosphorus $(\mathrm{P})$, potassium $(\mathrm{K})$, calcium $(\mathrm{Ca})$, sulfur $(\mathrm{S})$ and magnesium (Mg) (Popović, 2010; Vukadinović and Bertić, 2013).

The yield per unit area is the result of the action of factors of variety in interaction with environmental factors. The yield is largely dependent on the genetic potential and considerably vary primarily as a result of agro-ecological conditions during the growing season (Popović et al., 2011; Đekić et al., 2017a; 2017b; Terzić et al., 2018; Đekić et al., 2019). For high yield and grain quality, it is necessary to adopt nitrogen by plants during the whole vegetation period. Understanding the fertilization, liming and rainfall effects have been a continuous endeavor toward improving farming technology and management strategy to reduce the negative impacts of these factors and to increase crop yield (Popović et al., 2011; Ugrenović et al., 2018; Rajičić et al., 2019).

The two sides of agricultural constraints are production and marketing. From production side, smallholder farmers, particularly in developing country encounters multiple biotic and constraints abiotic such as inadequate planting material, pests and diseases, poor access to improved germplasm, low labor productivity and unreliable climatic conditions and from marketing side low market price, poor marketing infrastructure, low market integration, and this has led to low agricultural productivity and low supply of agricultural products on the market (Birachi et al., 2011). HLs shows that an effective, excellent, integrated and responsive market that is marked with good performance is of crucial importance for optimal allocation of resources and stimulating households to increase output (FAO, 2003).

In Serbia, the volume of wheat production and consumption is steadily increasing, over the last two decades (Popović, 2010). The aim of this study was to analyze wheat production in Bosnia and Herzegovina and suggest improvement productivity, efficiency and application of marketing management.

\section{MATERIAL AND METHODS}

This paper analyzes the wheat production parameters in the world during the period from 2010 to 2016. The research is based on the available data already existing in related statistical publications. Data from FAO 2018 were used, http:// faostat.fao.org / and Statistical Yearbook, B\&H. For the calculation of the yield and the size of the area, we used a basic statistical method comprising of the following:

-for calculation of variation degree of area size and yield coefficient of variation

(CV) was applied in equation:

$$
\mathrm{C}_{\mathrm{v}}=\mathrm{b} \cdot 100 / \bar{X}
$$

-movement of occurrences was calculated using an exponential trend in equation:

$$
\mathrm{Yt}=\mathrm{a} \cdot \mathrm{b}^{\mathrm{xi}} \text {. }
$$




\section{RESULTS AND DISCUSSION \\ Meteorological conditions}

Meteorological conditions were recorded high variability during year. In addition to the necessary reserve for the spring part of the vegetation, winter precipitation greatly influences the distribution of easily accessible nitrogen in the soil (Đekić et al., 2017b, 2019; Popović et. al., 2011; Terzić et al., 2018). This study was conducted over a ten-year period in the Bosnia and Herzegovina. In a temperate continental climate having an average annual temperature of $13.05^{\circ} \mathrm{C}$, and a rainfall amount of about $698.32 \mathrm{~mm}$, Graph 1.

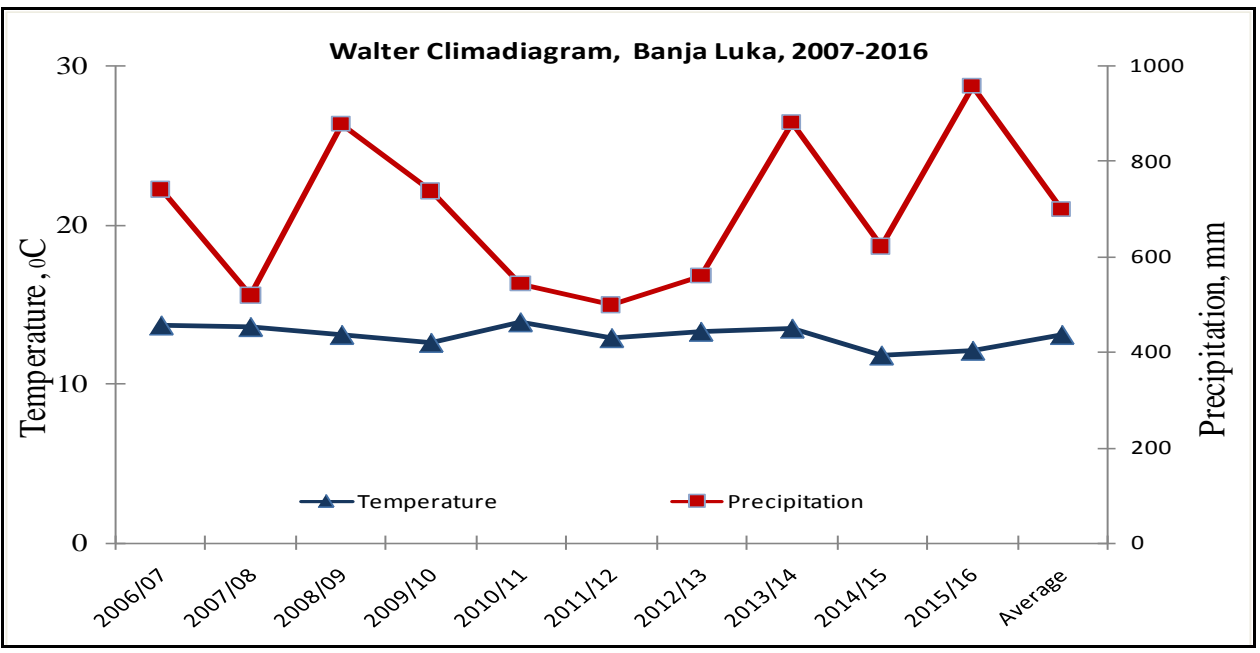

Graph. 1. Annual temperature, ${ }^{\circ} \mathrm{C}$, and precipitation, mm, 2006/07-2015/16

The most favorable year for production was 2016 when record yields of $4.3 \mathrm{t} \mathrm{ha}^{-1}$ were achieved, while the lowest yields were achieved in 2010, $2.7 \mathrm{t} \mathrm{ha}^{-1}$, Table1, Graph. 1.

\section{Production of wheat in $\mathbf{B} \& \mathbf{H}$}

Production of wheat in Bosnia and Herzegovina, (B\&H), had been growing 1.05 per cent per annum during the overall period (2007 to 2016). The coefficient of variation method was used to estimate the extent of instability in production, area and productivity of wheat crop. The coefficient of variation for wheat productivity of the B\&H revealed 20.45 per cent during the study period. Popović (2010) states that the similar trend was observed in Serbia.

Wheat is planted to an average of 63606.3 hectares in B\&H. There is an increasing trend of areas under wheat with a rate of $0.99 \%$ per year and variation $(\mathrm{CV}=8.01 \%)$. The highest areas of wheat, in the B\&H, was in $2016(71394.00$ ha), 2009 (68102.00 ha), 2013 (67902 ha) and 2015 (67644 ha). The smallest area under wheat was in 2010 (55454 ha) and the largest in 2016 (71,394 ha). In 2016, the area was increased by 11954 ha or $21.56 \%$ compared to 2010, Table 1. 
Wheat production an average of 255780 ha in B\&H. The highest production of B\&H of wheat was realized in 2016 (306600 t / ha), 2013 (265150 $\mathrm{t} \mathrm{ha}^{-1}$ ) and 2009 (255840 $\mathrm{t} \mathrm{ha}^{-1}$ ). A statistically significant decrease in wheat production was achieved in 2010 (145410 t ha ${ }^{-1}$ ) and 2014 (170000 t ha $\left.{ }^{-1}\right)$ compared to all examined years. Wheat production was higher in 2016 by 110.85 \% compared to 2010, Table 1 and Graph 2.

Average yield of wheat in the period 2007-2016 was $3.58 \mathrm{t} \mathrm{ha}^{-1}$ in total and have a tendency to increase with a rate of $0.45 \%$. Yield of wheat grains recorded increasing trend and variation $(\mathrm{CV}=13.02 \%)$. The highest yield was achieved in 2016 (4.3 $\mathrm{t} \mathrm{ha}^{-1}$ ) and the lowest in 2010. In 2016, a higher yield was produced for 1.60 t ha $^{-1}$ compared to 2010, Table 1 and Graph. 2.

Table 1. Wheat area, ha, yield, t/ha, moisture, \%, and production, t, B\&H

\begin{tabular}{|c|c|c|c|c|c|}
\hline $\begin{array}{r}\text { Parameter } \\
\text { Year }\end{array}$ & $\begin{array}{c}\text { Area } \\
\text { (ha) }\end{array}$ & $\begin{array}{l}\text { Production } \\
(000 \text { t) }\end{array}$ & $\begin{array}{l}\text { Yield } \\
\text { (t/ha) }\end{array}$ & $\begin{array}{c}\text { Import } \\
(000 \text { t) }\end{array}$ & $\begin{array}{l}\text { Export } \\
(000 \text { t) }\end{array}$ \\
\hline 2007 & 61124.00 & 226.06 & 3.70 & 374.70 & 2.98 \\
\hline 2008 & 64829.00 & 240.53 & 3.70 & 326.80 & 1.17 \\
\hline 2009 & 68102.00 & 255.84 & 3.80 & 316.77 & 13.78 \\
\hline 2010 & 55445.00 & 145.41 & 2.70 & 320.99 & 43.40 \\
\hline 2011 & 59440.00 & 210.00 & 3.60 & 344.17 & 1.81 \\
\hline 2012 & 61073.00 & 225.14 & 3.71 & 341.02 & 3.80 \\
\hline 2013 & 67902.00 & 265.15 & 3.90 & 280.00 & 45.30 \\
\hline 2014 & 59110.00 & 170.00 & 2.90 & 385.60 & 30.50 \\
\hline 2015 & 67644.00 & 213.10 & 3.50 & 337.00 & 29.80 \\
\hline 2016 & 71394.00 & 306.60 & 4.31 & 398.75 & 84.15 \\
\hline Average & 63606.30 & 225.78 & 3.58 & 342.58 & 41.75 \\
\hline $\begin{array}{l}\text { Rate of } \\
\text { change }\end{array}$ & 0.99 & 1.05 & 0.45 & 0.82 & 25.67 \\
\hline CV & 8.01 & 20.45 & 13.02 & 10.37 & 104.41 \\
\hline
\end{tabular}

Average export of wheat in the tested period was $41750 \mathrm{t}$ and notes a tendency to increase with a rate of $25.67 \%$ and variation $(\mathrm{CV}=104.41 \%)$. The highest import was achieved in 2016 (84150 t) and the lowest in 2008, 2011, 2017and 2012. In 2016,significantly higher export was achieved compared to 2008. Achieved difference was of 82980 t, Table 1 and Graph. 3.

Average import of wheat in the 2007-2016 period was $398750 \mathrm{t}$ and notes a tendency to increase with a rate of $0.82 \%$ and variation $(C V=10.37 \%)$. The highest import was achieved in 2016 (398750 t) and the lowest in 2013. In 2016 achieved significantly higher export compared to 2013, a difference of $118870 \mathrm{t}$ was achieved, that is, 42.41\%, Table 1 and Graph. 3. 


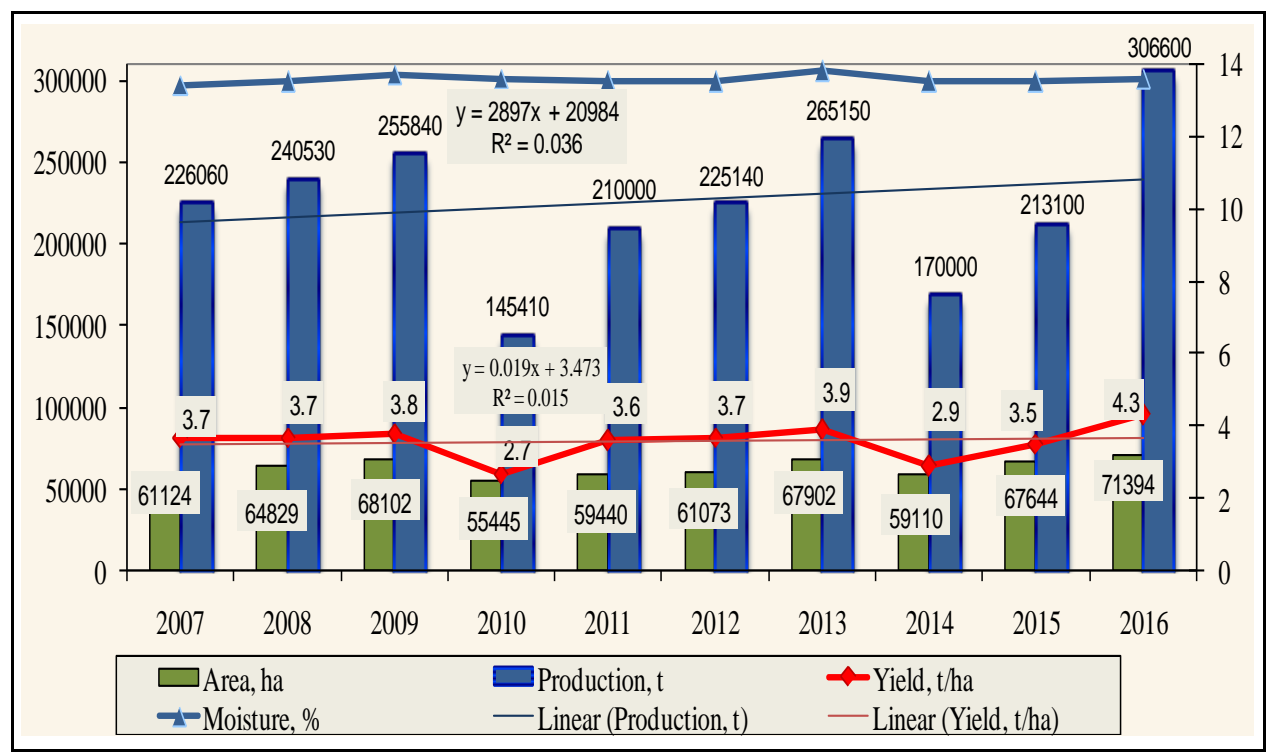

Graph. 2. Wheat area, ha, yield, t/ha, moisture, \%, production, B\&H, 2007-16

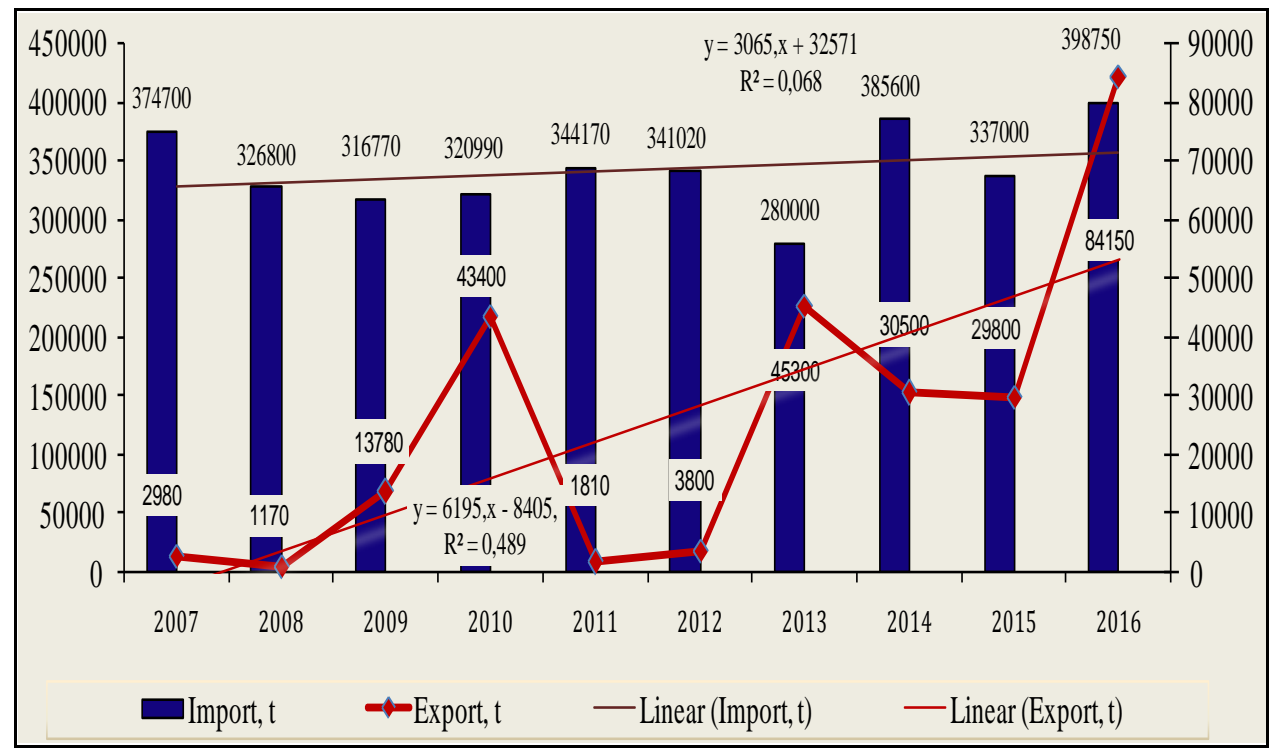

Graph. 3. Wheat import, t, and export, t, in B\&H, 2007-2016

Wheat is, in the world, the third largest crop by producing, and therefore contributes greatly to the world economy.

Wheat is the most widely grown cereal crop in the world, covering about 220 million hectares annually and giving for a total of 590 million tonnes 
(Popović, 2010; Šarčević-Todosijević et al., 2016; Lakić et al., 2018), and so it makes at least one-fifth calories ingested by man (Glamočlija et al., 2015). Average yield of wheat in Bosnia and Herzegovina in tested period 2010-2016, was about $3.58 \mathrm{t} \mathrm{ha}^{-1}$. Serbia the world's important wheat producer.

According to FAO (2017), all types of wheat in the Republic of Serbia are cultivated in the about 588.820 ha. In addition to the main product, grain, significant quantities of by-products are remaining in the field, in warehouses and in industrial production and processing (Rakaščan et al., 2019). In 2016, Serbia had a very good wheat crop of over 2.89 million tonnes, which had harvested from 595,000 ha. The initial wheat stock in 2018 was 218,000 tonnes with 3.11 million tonnes of wheat, available for consumption. Wheat needs in grain, in Serbia were about 1.55 million tonnes. For domestic consumption it required $1,200,000$ tones, for supplies 200,000 tonnes and for seed production 150,000 tonnes, while the rest was intended for export (about 1.34 million tonnes). The largest exports were to Romania, 343,576 tonnes, then to Kosovo about 95,000 tonnes, and large buyers also were Bosnia and Herzegovina (108,862 tonnes), Albania (43,009 tonnes), Montenegro (28,162 tonnes), Macedonia (21,782 tonnes), Italy with $(14,468$ tons), Croatia (1,555 tons), Slovenia (10 tons) and other countries with 1,579 tons. In the second half of 2016, exports were slightly weaker due to the high export price of wheat produced in Serbia (Gulan, 2017).

Grain yield is the most important parameter in wheat production, however, besides grain, wheat biomass is of great importance. Harvesting residues can be used in many ways: as livestock food, livestock straw, for ploughing in, for mulching, composting or preparing artificial manure, as energy recovery material and as construction material (Manojlović and Jaćimović, 2014; Živanović et al., 2017). The chemical composition and mass of the harvested residues is highly dependent on the plant species, genotype, climatic and weather conditions of the year, soil fertility and applied agro-technology. On average, plant dry matter contains about $45 \%$ carbon $(\mathrm{C}), 42 \%$ oxygen $(\mathrm{O}), 6.5 \%$ hydrogen $(\mathrm{H}), 1.5 \%$ nitrogen $(\mathrm{N})$ and $0.5 \%$ minerals. Cereal straw contains about $45 \%$ of carbon while maize cob contains about $57 \%$ of it (Kastori and Tešić, 2006). The mass of crop residues (straw, trees, leaves, roots) in plant production can be quite large. For example, in production of maize up to $12 \mathrm{t} \mathrm{ha}^{-1}$, wheat 4-6 tha $\mathrm{s}^{-1}$,sunflower about 4-5 tha ${ }^{-1}$, soybean about 4 tha $^{-1}$, and in sugar beets as much as 40-60 tha ${ }^{-1}$. From the above data, it can be seen that, by ploughing, a significant amount of nutrients returns to the soil (Jaćimović et al., 2017). External trade of agroindustrial products and trade liberalization implies the necessity of raising the technological level of production, productivity, efficiency and application of marketing management. Increased competition in the domestic market should contribute to increasing the quality and supply of goods. In order to dynamize exports, it is necessary to take advantage of the comparative advantages of the agro-industry, namely: favourable agro-ecological conditions, existence of significant capacities of the food industry, expert staff, etc. All the above factors should be in the function of creating stable export surplus products that will meet 
the market's needs in quality. It is necessary to stimulate the revival of all agricultural production through appropriate economic measures, which is a necessary precondition for exports. There is also a need for constant research into the needs and requirements of the market and for agro-industrial products to be adapted to the standards that govern the market: ISO, HACCP, GLOBAL GAP; in terms of product quality, size, packaging method, type of packaging, etc. Export prices of agro-industrial products should be competitive in the market. Presnall (2003) state that price competitiveness is no longer a determining export advantage, and qualitative factors that have proven to be decisive are: design, packaging, reliability and speed of delivery, brand, the ability to meet specific consumer demands at use, services during and after purchase, warranty periods and compliance with contractual obligations in the export business, the issue of patents, introduction and use, permanent advertising in the media, representing trade interests of our country and building a positive image of the company products and promotion of national identity. The international competitiveness of the national economy is based on the measurement and comparison of macroeconomic indicators and living standards, where productivity is in focus, while in the narrow sense it is defined as a country's ability to export its products to the world market (Leko-Simic, 1999; Mihailović, 2005). Promotional activities need to be defined in order to increase exports. In order for the Republic of Serbia and Bosnia and Herzegovina to increase its exports, its products must be competitive in quality, range and prices. This implies effective, market-oriented, profitable, product programs tailored to requests and needs of consumers. Competitiveness in the market can be increased by constant changes in production and market orientation, i.e. defining products according to the needs and requirements of the foreign market. Long-term cooperation with foreign partners is necessary and it is necessary to permanently raise the quality of the product while reducing production costs.

\section{CONCLUSIONS}

Based on the results attained during the research we can conclude the following:

Wheat production an average of 255780 ha in B\&H. Wheat production was higher in 2016 by $110.85 \%$ compared to 2010. Average export of wheat in the tested period was $41750 \mathrm{t}$ and notes a tendency to increase with a rate of $25.67 \%$ and average import of wheat was $398750 \mathrm{t}$ and it showed tendency to increase, with a rate of $0.82 \%$.

The basic direction for the future development of the agro-industry in $\mathrm{B} \& \mathrm{H}$ and in Serbia is the optimal use and available production capacities, increasing the volume of agricultural production of goods that are continuously imported. It is necessary to change the production structure in favour of intensive production intended for export, of production of high-final and high-quality products, while improving competitive position, in order to meet domestic demand and significantly reduce the import of agricultural food products. 


\section{ACKNOWLEDGMENTS}

This study was supported by the Ministry of Education, Science and Technological Development of the Republic of Serbia, and was created as a result of the projects: TR 31025 (2011-2020) and bilateral projects (R. of Serbia and Montenegro; 2019-2020): Alternative cereals and oil crops as a source of healthcare food and an important raw material for the production of biofuel and FAO project: Redesigning the exploitation of small grains genetic resources towards increased sustainability of grain-value chain and improved farmers' livelihoods in Serbia and Bulgaria - GRAINEFIT; 2019-2022.

\section{REFERENCES}

Asodiya, Pinakin S. (2014): Marketing and value addition of wheat in South Gujarat. Doctoral Theses. Navsari Agricultural University, Navsari http://krishikosh.egranth.ac.in/handle/1/65854

Birachi EA, Ochieng J, Wozemba D, Ruraduma C, Niyuhire MC, et al. (2011): Factors LnfluencLng smallholder farmers' bean production and supply to market in Burundi. African Crop Science Journal 19: 335-342.

FAO (Food and Agricultural Organization) (2003) FAO action program for the prevention of food loses. Milk and dairy products, post-harvest loses and food safety in sub-Saharan Africa and the near east. Regional approaches to national challenges. Synthesis report. ILRI, Nairobi, Kenya

Pedrotti, W. (2003): Cereal properties, application and action. Book. Natural medicine. Zagreb, 1-125.

Vukadinović, V, Bertić, B. (2013): Fertilization philosophy. Book. Osijek. 1-125.

Glamočlija, Đ., Janković, S., Popović, M.V., Kuzevski, J., Filipović, V., Ugrenović, V. (2015): Alternatively crop plants in conventional and organic growing systems. Monograph. Belgrade, ISBN 978-86-81689-32-5; 1-355

Gulan B. (2017). Proizvodnja i izvoz pšenice 2017. https://www. makroekonomija.org/poljoprivreda/proizvodnja-i-izvoz-psenice2017

Kastori, R., Tešić, M. 2006. Ekološki aspekti primene žetvenih ostataka njivskih biljaka kao alternativnog goriva, Zbornik radova, Institut za ratarstvo i povrtarstvo, Novi Sad, 42: 3-13.

Jaćimović G., Aćin V., Crnobarac J., Latković D., Manojlović M. (2017). Efekti zaoravanja žetvenih ostataka na prinos pšenice u dugotrajnom poljskom ogledu. / Effects of crop residue incorporation on the wheat yield in a long-term experiment. Letopis naučnih radova / Annals of Agronomy. 41: 1-8.

Lakić Ž., Glamočlija Đ., Kondić, D., Popović V., Pavlović S. (2015): Krmne biljke i žita u funkciji zaštite zemljišta od degradacije. Monografija. Republika Srpska. 1-405.

Leko-Šimić, M., (1999): Međunarodna konkurentnost hrvatskog gospodarstva u okruženju tranzicijskih zemalja srednje i istočne Europe, Tržište, Ekonomski fakultet Osijek, 10-10.

Maksimović L., Popović V., Stevanović P. (2018). Water and irrigation requirements of field crops grown in central Vojvodina, Serbia. Agriculture and Forestry, Podgorica, 64, 1, 133-144. DOI: 10.17707/AgricultForest.64.1.16

Manojlović, M., Jaćimović, G. 2014. Značaj zaoravanja žetvenih ostataka za kvalitet zemljišta, produktivnost i prilagođavanje klimatskim promenama. Naučno-stručno savetovanje „Dobar dan domaćine“, 23.01.2014. Novi Sad. Univerzitet u Novom Sadu, Poljoprivredni fakultet, Tematski zbornik radova, 
Mihailović, B. (2005). Marketing. Book. Podgorica, Montenegro. 400.

Đekić, V., Jelić, M.,Milivojević, J.,Popović, V.,Branković, S., Staletić, M., Terzić, D. (2017a): Winter wheat yield and yield components depending on the level of nitrogen, phosphorus and potassium fertilization. Proceedings, VIII International Scientific Agriculture Symposium "Agrosym 2017", Jahorina, 650-657.

Đekić, V., Popović, V., Branković, S., Terzić, D., Đurić, N. (2017b): Yield components and grain yield of winter barley. Agriculture and Forestry, 63 (1): 179-185, DOI: 10.17707/AgricultForest.63.1.21

Đekić, V., Popović, V., Terzić, D., Đurić, N., Perišić, V., Perišić, V., Luković, K. (2019): The impact of climate change on the grain yeald of wheat. Proceedings of research papers PKB Agroekonomik, Belgarde, 25(1-2): 9-18.

Pavicevic Lj. (1991): A study of rare species of wheat in Montenegro. Agriculture and Forestry, 37 (1-2), 55-62.

Pavićevic, Lj. (1992): About promotion bare wheat tetraploid in the Southern coastal belt Yugoslavia, Agriculture and Forestry, 38, 3-4, 3-12

Popović V. (2010): Agro-technical and agro-ecological influence on the production of wheat, maize and soybean seeds. Doctoral dissertation, University of Belgrade, Faculty of Agriculture, Zemun, 1-145., 3-15.

Popović V., Glamočlija Đ., Malešević M., Ikanović J., Dražić G., Spasić, M., Stanković S. (2011): Genotype specificity in nitrogen nutrition of malting barley. Genetika, Belgrade, 43 (1), 197-204.

Rajičić V., Milivojević J., Popović V., Branković S., Đurić N., Perišić V., Terzić D. (2019). Winter wheat yield and quality depending on the level of nitrogen, phosphorus and potassium fertilization. Agriculture \& Forestry, Podgorica, DOI:10.17707/AgricultForest.65.2.06, 65, 2: 79-88

Rakascan N., Dražić, G., Živanović Lj., Ikanović J., Jovović Z., Lončar M., Bojović R. and Popović V. (2019): Effect of genotypes and locations on wheat yield components. Agriculture \& Forestry, Vol. 65 Issue 1: 233-242, Podgorica, DOI: 10.17707/AgricultForest.65.1.23

Presnall, A. (2003.): Konkurentnost privrede Srbije, Jefferson Institute, Beograd.

Šarčević-Todosijević LJ., Živanović LJ., Popović V., Ikanović J., Popović S., Drazić G. (2016): The influence of nitrogen fertilizer on the total number of microorganisms and aminoautotroph dynamics under 'Ugar' and sown maize. Agriculture and Forestry, 62 (3): 185-196.

Terzić, D., Đekić, V., Milivojević, J., Branković, S., Perišić, V., Perišić, V., Đokić, D. (2018): Yield components and yield of winter wheat in different years of research. Biologica Nyssana, 9 (2): 119-131.

Ugrenović, V., Bodroža Solarov, M., Pezo, L., Đisalov, J., Popović, V., Marić, B., Filipović, V. (2018): Analysis of spelt variability (Triticum spelta L.) grown in different conditions of Serbia by organic conditions. Genetika, 50 (2): 635-646.

Živanović Lj., Savić J., Kolarić Lj., Ikanović J., Popović V., Novaković M. (2017): The influence of genotype on wheat, soybean, corn and sunflower grain yield. Institute of PKB Agroekonomik, Belgrade, 23 (1-2): 39-48. 